\title{
The invasive land planarian Platydemus manokwari (Platyhelminthes, Geoplanidae): records from six new localities, including the first in the USA
}

Jean-Lou Justine, Leigh Winsor, Patrick Barrière, Crispus Fanai, Delphine Gey, Andrew Kien Han Wee, Giomara La QuayVelázquez, Benjamin P. Y-H. Lee, Jean-Marc Lefevre, Jean-Yves Meyer, David Philippart, David G. Robinson, Jessica Thévenot, Francis Tsatsia

The land planarian Platydemus manokwari de Beauchamp, 1963 or "New Guinea flatworm" is a highly invasive species, mainly in the Pacific area, and recently in Europe (France). We report specimens from five additional countries and territories: New Caledonia (including mainland and two of the Loyalty Islands, Lifou and Maré), Singapore, Solomon Islands, Puerto Rico, and Florida, USA. We analysed the COI gene (barcoding) in these specimens with two sets of primers and obtained 909 bp long sequences. In addition, specimens collected in Townsville (Australia) were also sequenced. Two haplotypes of the COI sequence, differing by 3.7\%, were detected: the "World haplotype" found in France, New Caledonia, French Polynesia, Singapore, Florida and Puerto Rico; and the "Australia haplotype" found in Australia. The only locality with both haplotypes was in the Solomon Islands. The country of origin of Platydemus manokwari is New Guinea, and Australia and the Solomon Islands are the countries closest to New Guinea from which we had specimens. These results suggest that two haplotypes exist in the area of origin of the species, but that only one of the two haplotypes (the "World haplotype") has, through human agency, been widely dispersed. However, since $P$. manokwari is now recorded from 21 countries in the world and we have genetic information from only 8 of these, with none from New Guinea, this analysis provides only partial knowledge of the genetic structure of the invasive species. Morphological analysis of specimens from both haplotypes has shown some differences in ratio of the genital structures but did not allow us to interpret the haplotypes as different species. The new reports from Florida and Puerto Rico are the firsts for the USA, for the American continent, and the Caribbean. P. manokwari is a known threat for endemic terrestrial molluscs and its presence is a matter of concern. While most of the infected territories reported until now are islands, the newly reported presence of the species in mainland US in Florida should be considered a potential major threat to the whole US and even the Americas. 
2 The invasive land planarian Platydemus manokwari (Platyhelminthes, Geoplanidae): records from six 3 new localities, including the first in the USA

Jean-Lou Justine*, Leigh Winsor, Patrick Barrière, Crispus Fanai, Delphine Gey, Andrew Wee Kien Han,

6 Giomara La Quay- Velázquez, Benjamin Paul Yi-Hann Lee, Jean-Marc Lefevre, Jean-Yves Meyer, David

7 Philippart, David G. Robinson, Jessica Thévenot, Francis Tsatsia **

8 * Corresponding author

$9 \quad * *$ Authors are listed alphabetically, except for the first and second one.

10 Jean-Lou Justine, Institut de Systématique, Évolution, Biodiversité, ISYEB, UMR7205 CNRS, EPHE, MNHN, UPMC, 11 Muséum National d'Histoire Naturelle, Sorbonne Universités, CP 51, 57 rue Cuvier, 75231 Paris cedex 05, France

12 Patrick Barrière, Conservatoire d'espaces naturels de Nouvelle-Calédonie (CEN NC), Pôle espèces envahissantes 13 (PEE), Presqu'Île de Foué, BP 10, 98860 Koné, New Caledonia

14 Delphine Gey, Service de Systématique moléculaire, Muséum National d’Histoire Naturelle, Paris, France

15 Andrew Wee Kien Han, SingHealth Polyclinics, Marine Parade, Blk 80, Marine Parade Central, \#01-792, Singapore 16440080

17 Giomara La Quay-Velázquez, Department of Biology, Universidad de Puerto Rico, Rio Piedras Campus, San Juan, 18 Puerto Rico 00931-3360, USA

19 Benjamin Paul Yi-Hann Lee, (1) Durrell Institute of Conservation \& Ecology, University of Kent, United Kingdom; (2) 20 National Parks Board, Singapore

21 David Philippart, FREDON de Basse Normandie, 4 place de Boston, Bâtiment Ambassadeur A, 14200 Hérouville22 Saint-Clair, France

23 David G. Robinson, USDA APHIS National Malacology Laboratory, Academy of Natural Sciences, 1900 Benjamin 24 Franklin Parkway, Philadelphia, PA 19103-1101, USA Jessica Thévenot, Service du Patrimoine Naturel, Muséum National d’Histoire Naturelle, France Jean-Marc Lefevre, Environnement et Cadre de Vie, Ville de Caen, Caen, France Jean-Yves Meyer, Délégation à la Recherche, Gouvernement de la Polynésie française, BP 20981, 98713 Papeete, Tahiti, French Polynesia

Crispus Fanai, Francis Tsatsia, Biosecurity Solomon Islands, Ministry of Agriculture and Livestock, PO Box G13, Honiara, Solomon Islands 


\section{Introduction}

The land planarian Platydemus manokwari de Beauchamp, 1963 or "New Guinea flatworm" is an invasive species, recorded in 15 countries in the World, and recently in France in a hothouse (Justine et al. 2014b). Platydemus manokwari is the only flatworm listed in the "100 world's worst invasive alien species" (Lowe et al. 2000); it is a predator of land snails and is considered a danger to endemic snails wherever it has been introduced. Its distribution records, reproduction, biology, prey lists, impacts, and possible control options were recently reviewed (Justine et al. 2014b).

Alien land planarians, generally originating from the Southern Hemisphere or from tropical Asia, are now found in all parts of the world (Álvarez-Presas et al. 2015; Álvarez-Presas et al. 2014; Breugelmans et al. 2012; Cannon et al. 1999; Jones 1998; Jones 2005; Justine et al. 2014a; Kawakatsu et al. 2002; LagoBarcia et al. 2015; Mateos et al. 2013) and some of these more invasive flatworms pose a threat to local species that are included in their prey, including earthworms (Boag et al. 1994; Boag \& Yeates 2001; Jones et al. 2001; Murchie \& Gordon 2013) and snails (Winsor et al. 2004).

We report here the presence of $P$. manokwari in several additional countries and territories: Singapore, New Caledonia (including mainland and two of the Loyalty Islands), an additional island in French Polynesia, Wallis and Futuna (from two of the islands, Uvea and Futuna), the Solomon Islands, Puerto Rico and Florida, USA - the latter being the first records on the American continent. We show that barcodes of specimens comprise two haplotypes, one found in many localities in the world and one found in Australia. Specimens from the Solomon Islands were the only ones to show genetic diversity, with both haplotypes present in the same locality.

\section{Material and methods}

\section{Origin of new reports}

The new findings reported here were collected thanks to a worldwide campaign in several steps: (a) a paper published in this journal (Justine et al. 2014b); (b) its accompanying press releases; (c) a worldwide interest by the international media, with articles in more than 15 languages (some media enumerated here: https://peerj.com/articles/297/\#links); (d) the wide dissemination of the paper, which was open-access and available from the publisher's website, PubMed Central, Academia.edu, and ResearchGate; (e) a "question" asked on the social networking site ResearchGate 
(https://www.researchgate.net/post/Have_you_seen_this_land_planarian_an_invasive_alien_species);

(f) for France, a citizen science survey, based on a blog (Justine 2014) and a twitter account

(https://twitter.com/Plathelminthe4); (g) for New Caledonia (including the Loyalty Islands), a general survey officially organized by one of us (PB), which involved 140 technical partners from local administrations, research institutions and plant nurseries (see Table 1).

Photographs of $P$. manokwari (Figs 1-4) were obtained from various sources (Table 1).

\section{Fixation of worms}

For fixation, two protocols were used: either (a) the living specimen was simply put into roomtemperature ethanol (80-95\%); or (b) the living worm was put into boiling water; after 1-2 minutes water was removed and replaced with room-temperature ethanol (80-95\%). No narcotizing agents were used. Specimens of $P$. manokwari (Table 1), collected by hand and fixed, were sent to Paris by postal service. In addition, we collected new specimens from the infested hothouse in Jardin des Plantes, Caen, France and in public and private gardens in Townsville, Australia. Specimens were deposited in the collections of the Muséum National d'Histoire Naturelle, Paris, France (MNHN), and the United States Department of Agriculture, Animal and Plant Health Inspection Service (USDA APHIS) National Malacology Laboratory, Academy of Natural Sciences, Philadelphia, USA.

\section{Anatomical analysis}

In order to determine whether the two main haplotypes could be recognized morphologically the dimensions of various characters were measured in three sexually mature specimens of the World haplotype (MNHN JL139, 201F and 201G all from Dodo Creek, Solomon Islands), and in three specimens of the Australian haplotype (GenBank AF178320/ LW1065 from Townsville, and MNHN JL201A and 201B from Dodo Creek, Solomon Islands). The posterior portion of mature specimens that were selected for both molecular analysis and histology (Table 2) were given a second change of absolute ethanol, then transferred to xylene, and finally infiltrated and embedded in Paraplast ${ }^{\circledR}$ Tissue Embedding Medium. Tissue blocks were sectioned at $8 \mu \mathrm{m}$ in the longitudinal sagittal plane using a rotary microtome, then affixed to slides with glycerine-egg albumen, stained using the trichrome Picro-Gomori method (Menzies 1959), and mounted in D.P.X with colourfast (Fronine, Riverstone, Australia).

\section{Molecular sequences}


90

For molecular analysis, a small piece of the body $\left(1-3 \mathrm{~mm}^{3}\right)$ was taken from the lateral edge of ethanolfixed individuals. Genomic DNA was extracted using the QIAamp DNA Mini Kit (Qiagen). Two sets of primers were used to amplify the COI gene. A fragment of $424 \mathrm{bp}$ (designated in this text as "short sequence") was amplified with the primers COI-ASmit1 (forward 5'-TTTTTTGGGCATCCTGAGGTTTAT-3') and COI-ASmit2 (reverse 5'-TAAAGAAAGAACATAATGAAAATG-3') (Littlewood et al. 1997). The PCR reaction was performed in $20 \mu \mathrm{l}$, containing $1 \mathrm{ng}$ of DNA, $1 \times$ CoralLoad PCR buffer, 3Mm MgCl2, $66 \mu \mathrm{M}$ of each dNTP, $0.15 \mu \mathrm{M}$ of each primer, and 0.5 units of Taq DNA polymerase (Qiagen). The amplification protocol was: $4^{\prime}$ at $94^{\circ} \mathrm{C}$, followed by 40 cycles of $94^{\circ} \mathrm{C}$ for $30^{\prime \prime}, 48^{\circ} \mathrm{C}$ for $40^{\prime \prime}, 72^{\circ} \mathrm{C}$ for $50^{\prime \prime}$, with a final extension at $72{ }^{\circ} \mathrm{C}$ for $7^{\prime}$. A fragment of 825 bp was amplified with the primers BarS (forward $5^{\prime}$ GTTATGCCTGTAATGATTG-3') (Álvarez-Presas et al. 2011) and COIR (reverse 5'CCWGTYARMCCHCCWAYAGTAAA-3') (Lázaro et al. 2009), following (Mateos et al. 2013). PCR products were purified and sequenced in both directions on a 3730xI DNA Analyzer 96-capillary sequencer (Applied Biosystems). Results of both analyses were concatenated to obtain a COI sequence of $909 \mathrm{bp}$ in length (designated in this text as "long sequence"). Sequences were edited using CodonCode Aligner software (CodonCode Corporation, Dedham, MA, USA), compared to the GenBank database content using BLAST and deposited in GenBank under accession number KR349579-KR349611 and xxx-xxx. A newly obtained sequence of Parakontikia ventrolineata, GenBank KR349587, from a specimen collected in Brest (France) and kept in the MNHN collection as MNHN JL95, was used as outgroup for the NJ tree. For several specimens only "short" sequences were obtained (Table 1). No sequence was obtained for the specimens from Guam (Table 1), which were kept in ethanol for a decade.

\section{Trees and distances}

MEGA6 (Tamura et al. 2013) was used to estimate genetic distances ( $p$-distance and also kimura-2 parameter distance) and the evolutionary history (Figs 5-6) was inferred from the kimura-2 parameter distance using the Neighbour-Joining method (Saitou \& Nei 1987); all codon positions were used.

\section{Results}

\section{Analysis of molecular data}

We obtained $\mathrm{COI}$ sequences from 38 individuals. Of these, 21 were "long" sequences, obtained with two pairs of primers, and 17 were "short" sequences, when only one pair of primers provided results. 
119 The analysis of the 38 "short" sequences showed that only two haplotypes were present. One haplotype 120 was found in specimens from France, French Polynesia, New Caledonia, Singapore, Florida and Puerto 121 Rico, and certain specimens from the Solomon Islands; we designate it as the "World haplotype". One 122 haplotype was found only in specimens from Australia and certain specimens from the Solomon Islands; 123 we designate it as the "Australian haplotype". The difference between the two haplotypes was 15 bases, 124 on a total of 401 (p-distance: 3.7\%; kimura-2 parameter distance: $3.8 \%$ ); no individual variation of these 125 "short" sequences was found in any of the two haplotypes. A tree constructed from these sequences 126 shows two well differentiated branches, with identical sequences in each of the branches (Figure 5).

127 The analysis of the 21 long sequences also revealed the same two haplotypes, World and Australian. The 128 difference between the two haplotypes was 42 bases, on a total of 848 (p-distance: $4.8 \%$; kimura-2 129 parameter distance: 5.0\%). A minor variation was found in the Australian haplotype, with one specimen 130 having a one-base difference (distance from this specimen to the World haplotype: p-distance: $5.0 \%$; 131 kimura-2 parameter distance: 5.2\%); this haplotype is designated as "Australian 2" and the other, major 132 haplotype is designated as "Australian 1". No variation was found in the World haplotype (15 sequences 133 from four countries) for these long sequences. A tree constructed from these sequences shows two well 134 differentiated branches, with identical sequences in the World haplotype branch and minor variation in 135 the Australian haplotype branch (Figure 6).

136 Variation within localities was strikingly different between Dodo Creek, Solomon Islands and the rest of 137 the studied localities. All specimens from France (3), New Caledonia (9 from different localities), 138 Singapore, Florida and Puerto Rico ( 2 in each case) were identical and displayed the World haplotype; all 139 specimens from Townsville had the Australian haplotype with a minor difference of one base for one 140 specimen (haplotype Australian 2). Sequences from Henderson (Solomon Islands) were identical in the 141 five specimens, with haplotype Australian 1. In contrast, the ten specimens from Dodo Creek included 142 three animals with haplotype Australian 1 and seven with haplotype World. The Solomon Islands were thus the only country in which genetic variation among specimens was observed.

\section{Morphological identification}

145 The flatworms (Figs 1-4) presented the following morphological characteristics: body broadest in the 146 middle, tapering evenly anteriorly but more abruptly posteriorly; two large prominent eyes back from 147 the tip of the elongate snout-like head; dorsum a dark olive brown colour; pale cream median dorsal 148 longitudinal stripe beginning just behind the eyes and continuing to the posterior tip; olive brown colour 
149

grading to grey at anterior tip; two thin submarginal cream stripes with fine lower greyish margin running laterally from the anterior end along the length of the body; ventral surface a pale finely mottled light brown. These features are consistent with those of Platydemus manokwari de Beauchamp, 1963 (Platyhelminthes, Continenticola, Geoplanidae, Rhynchodeminae) (de Beauchamp 1962; Justine et al. 2014b; Kawakatsu et al. 1992; Winsor 1990).

The dimensions and characters that were compared between specimens of the two haplotypes included body length and width, the distance of the mouth and gonopore from the anterior end, the lengths of the oesophagus, pharynx and pharyngeal pouch, distance between the common sperm duct and common ovovitelline duct, distance from the common sperm duct to the tip of the penis papilla, penis length and penis width at it base, length of the male atrium, length of the female atrium, length of the glandular canal, length of the common ovovitelline duct and depth of the viscid gland. Sexually mature specimens of $P$. manokwari from the Solomon Islands were found to be considerably smaller $(22-28$ $\mathrm{mm}$ long) than those from Caen, France ( $44.5 \mathrm{~mm}$ long) and Townsville, Australia (45 $\mathrm{mm}$ long). The only characters that were found that may possibly differentiate between the two haplotypes are the length of the penis papilla expressed as a percentage of the total body length (Table 2), and the shape of the penis papilla. Specimens of the World haplotype generally exhibited a finger-shaped or elongate conical penis papilla that was $1.4-1.7 \%$ of the body length, similar in appearance of the copulatory organs of $P$. manokwari figured by de Beauchamp (Figs 1A, 1B in (de Beauchamp 1962)) whereas in specimens of the Australian haplotype the penis papillae tended to be a low regular conical shape with a length less than $1 \%$ of the total body length (0.7-0.9\% of the body length), closely resembling the copulatory organs of $P$. manokwari figured by de Beauchamp (Figure 1 in (de Beauchamp 1972)) and by Winsor (Winsor 1990) (Figure 1 in (Winsor 1998)).

\section{Time of invasion and other remarks}

In France, after the first finding of $P$. manokwari (October 2013), the hothouse of the Jardin des Plantes in Caen in which the species was found was closed and public access restricted. In April 2014, a thorough search was performed in the same hothouse. Several species of land planarians were found (some are still unidentified), including four adult specimens of $P$. manokwari. A citizen-based survey of land planarians in France (Thévenot et al. 2014), supported by important media involvement (list of links: https://peerj.com/articles/297/\#links), yielded hundreds of records of non-indigenous land planarians in France (Justine 2014; Justine et al. 2014a) but never a record of $P$. manokwari in the wild. 
179 The presence of the species in Singapore had already been noted in 2010, according to unpublished 180 observations listed in Table 1, and the species is probably spreading; according to the observations of 181 one of us (AWKH), the species was not present in his garden before 2013. Local observations show that P. manokwari predates the introduced giant African snail, Achatina fulica Bowdich, 1822.

183 The detection of $P$. manokwari in New Caledonia is recent (2014). After the discovery of the first specimens in the capital city, Nouméa, in April 2014, a survey was conducted from September 2014 to April 2015. Specimens were found in several places in the mainland, including Southern and Northern Provinces, and in two of the three Loyalty Islands, Maré and Lifou. The current extensive distribution of such a cryptic species, evidenced after only eight months of survey, suggests that the introduction of $P$. manokwari is not recent. Moreover, discussions with scientists involved in the observation of soil species revealed that the flatworm had been observed several years ago, but no substantiated proof of these observations could be found. Since a number of endemic land planarians exist in New Caledonia (Schröder 1924; Winsor 1991), it could not be ascertained if these earlier observations were actually of P. manokwari, or of other species. P. manokwari was not detected when large surveys were conducted in the 1990s (Gargominy et al. 1996) - it is thus likely that its introduction occurred in the 20 last years. Local observations show that $P$. manokwari predates introduced $A$. fulica.

In Wallis and Futuna, our records of $P$. manokwari are based only on two photographs taken by one of us (JYM), in 2007 in Uvea (Wallis Islands) and in 2008 in Futuna (Hoorn Islands). These two island groups are separated by more than $100 \mathrm{~km}$ of sea. No more recent records are available.

The presence of P. manokwari on Guam has been known since 1977 (Eldredge \& Smith 1995; Hopper \& Smith 1992). Our records, dated 2004, confirm the continuing presence of the species; to our knowledge, no more recent records are available.

201 In the USA, the accidental introduction of $P$. manokwari through human agency to Florida is probably recent, with our first specimens found in August 2012. The species is apparently now well established, with several different locations found in 2014 in Miami Dade County (Table 1). The introduction of $P$. manokwari to Puerto Rico is also probably recent, with the first specimens found in December 2014, in a single locality, San Juan (Table 1). To our knowledge, no survey aiming specifically at detecting $P$. manokwari has been done in other parts of Florida or in other US states. Land planarians are often 
209 The introduction of the species to Guadalcanal, Solomon Islands also seems recent (2014). Specimens of

210 P. manokwari were found in fields invaded by the introduced Giant African snail, Achatina fulica.

211 Although the report of these flatworms in Guadalcanal is recent, we do not know if this is truly an

212 indication of a recent introduction or not. The case of New Caledonia, where the species was found in

213 many localities after a coordinated participative survey was initiated, and, on the contrary, the case of

214 Guam, for which we have no report for the last decade, show that land planarians are detected and

215 reported only when an appropriate survey is undertaken. It is obvious that land planarians in Solomon

216 Islands, a country with low income and expensive internet access, are less often photographed by

217 amateur photographers who post their findings on the internet than they are in the US or Singapore.

218 Figure 7 shows all available records of $P$. manokwari in the world. The spread of the species mainly 219 concerns countries and territories in the Pacific Area; Florida and Puerto Rico are the first records in the 220 Americas. The record in Florida is the first on the American mainland.

\section{Discussion}

Morphological and molecular identification of specimens

224

The external morphological characteristics of the specimens found in the new locations, Singapore, Tahiti, New Caledonia, Wallis and Futuna, Solomon Islands, Florida and Puerto Rico, are similar to Platydemus manokwari from other locations. Histological examination of sexual specimens confirmed the identity of the species in Caen, France, the Solomon Islands, and Townsville, Australia.

The length and shape of the penis papillae may possibly reflect the relative maturity of the specimens (young sexual specimens compared to relatively older sexual specimens); unfortunately there are presently no data available for $P$. manokwari correlating the age of sexual specimens with the continuing development of the copulatory organs. Alternatively the length and shape of the penis papillae may in fact reflect differences between these two haplotypes. Based on observations of the partly extended and contracted penis of various specimens of the land planarians Parakontikia ventrolineata and Kontikia mexicana, it was concluded that "unless conditions of fixation are absolutely standard, penial protrusion must be regarded at best as an unreliable character" (Jones et al. 1998). All the specimens that were investigated in this study were killed without the use of a narcotizing agent and were fixed in ethanol. In the specimens examined histologically, the penis papilla was either the 
elongate finger-like conical shape or the low regular conical shape; there appeared to be no intermediary forms. Recently, the form of the penis papilla was included in the suites of characters used to morphologically distinguish between cryptic species revealed by molecular analysis (Álvarez-Presas et al. 2015), where in the copulatory organs of Obama decidualis the penis papilla was irregularly shaped, sometimes conical, otherwise much folded, compared to $O$. anthropophila in which the penis papilla had a regular conical form. However given the very small sample size in our study we hesitate to unequivocally state that the length and form of the penis papilla reliably differentiate one haplotype of Platydemus manokwari from the other.

Sequences of COI comprised two haplotypes, "Australian" (with a minor variation on a single nucleotide in a single specimen among 13) and "World" (France, New Caledonia, Singapore, Tahiti, Florida, Puerto Rico; all identical in 19 specimens). The two haplotypes were found together in the same locality only in the Solomon Islands. The difference between the two haplotypes was 3.7\% (computed on short sequences) and $4.8 \%$ (computed on long sequences). In the literature there are reports of variations in the intraspecific and interspecific genetic distances of species in the same family as $P$. manokwari, i.e. the Geoplanidae, For Microplana spp., specimens considered to belong to the same species varied by up to $4 \%$, and specimens from different species varied by $19 \%$ (Álvarez-Presas et al. 2012). In other genera, some species show high intraspecific values, up to 8.3\% (Lago-Barcia et al. 2015). The difference of 4.8\% between the two variants of $P$. manokwari found here could be either considered as relatively high intraspecific variation, or as evidence for the presence of two different species. In view of the limited morphological and anatomical differences found between specimens with known haplotypes, and the small size of our sample, we provisionally conclude that a single species, Platydemus manokwari, is involved.

\section{The world distribution of the two COI haplotypes}

The Solomon Islands contrast with all other localities in the world for which we have molecular data for P. manokwari: in all other localities a single haplotype was detected. Moreover, the same haplotype (which we named "World") was found in localities as distant as Solomon Islands, French Polynesia, New Caledonia, Singapore, Tahiti, France, Florida and Puerto Rico. This suggests that the species encountered a bottleneck of genetic diversity in the early stages of its human-mediated dispersal throughout the Pacific region and that all specimens found in these distant countries and territories come from an original population with low genetic variation. 
How do we interpret the presence of two haplotypes in the Solomon Islands? Platydemus manokwari was described from Papua New Guinea (de Beauchamp 1962) and was found in several localities in this large island, from the coast to an altitude of 3,000 m (de Beauchamp 1962; de Beauchamp 1972). We have, unfortunately, no information about the genetic structure of these populations, and our knowledge of the genetic variation in other places is based on a single marker, the COI gene. The Solomon Islands are less than 1,000 km away from the Eastern part of Papua New Guinea. Human contacts between these islands might be as ancient as 30,000 years (Sheppard 2011). For these reasons, it is either possible that $P$. manokwari was inadvertently transported from Papua New Guinea by early Melanesian settlers or that the invasion is extremely recent. The presence of both haplotypes in Solomon Island could be an indication that several populations were transported there from Papua New Guinea or Australia, at dates unknown. It remains that other countries and territories were invaded with two populations of $P$. manokwari, one with no genetic variation, which has been transported to many localities (the "World" COI haplotype) and one, with very low variation, which is found only in Australia (the "Australian" COI haplotype).

\section{Significance of these new records - a threat to biodiversity}

As far as we are aware, these records are the first of $P$. manokwari in Singapore, New Caledonia, Wallis and Futuna, the Solomon Islands, the Caribbean, and North America. They thus add six countries and territories to the list of 16 territories recently published, which included Irian Jaya, New Guinea, Australia, Guam and Northern Mariana Islands, Philippines, Japan, Maldives, Palau, Hawaii, Federated States of Micronesia, French Polynesia, Samoa, Tonga, Vanuatu, Fiji and France (Justine et al. 2014b).

In French Polynesia, records were known only from Moorea Island (Lovenburg 2009) and Mangareva Island (Justine et al. 2014b; Purea et al. 1998); the present records are the first from Tahiti Island, the main island of French Polynesia. However, Moorea is very close to Tahiti (15 km) with significant interisland traffic via several ferries, and it is not surprising that the two islands share the species. Of interest is that the species was recorded in Tahiti Island in two stations with different altitudes, sea level and about $1000 \mathrm{~m}$. This is the only locality for which we have altitude records; most other records are from close to sea level, though the species has been recorded from sea level to 3,000 in Papua New Guinea (de Beauchamp 1962; de Beauchamp 1972).

In New Caledonia, it was demonstrated by one of us (PB) that when a coordinated survey is organized, the knowledge about the distribution of a relatively cryptic species can be dramatically increased in a 
matter of months; although the first record in a private garden was made in April 2014, we have now confirmed records of $P$. manokwari in more than 15 locations, including both Southern and Northern Provinces and two of the Loyalty Islands. It is therefore clear that the species has been inadvertently spread to most of the provinces and main islands of New Caledonia.

In France, the current situation is that $P$. manokwari is confined to a single hothouse in the Jardin des Plantes in Caen, but is not eradicated. Eradication is still an issue of concern, because the species could be a major threat to various soil invertebrates, especially snails, including endemic species (Justine et al. 2014b).

Platydemus manokwari has now been found in 22 countries and territories in the world, mainly in the Pacific area (Fig. 7). It is thus clear that the genetic results presented here (from 8 countries and territories) represent only a fraction of these disjunct populations of the worm. A survey of the genetics of populations in the area of origin (Papua New Guinea) is necessary to fully interpret the results, as are the use of additional genetic markers; these are beyond the scope of this paper which relies on a single marker (COI) on a limited number of samples, with none from the country of origin. Our discovery of the existence of two haplotypes is potentially important for our understanding of the invasion by Platydemus manokwari, with, apparently, one haplotype more successful than the other.

Furthermore, while most of the infected countries and territories reported until now are islands, from which the spread of the species through human agency is limited by means of transportation and various business and biosecurity protocols, our new record, Florida, will not be subjected to these limitations. In addition to their natural spread, specimens of $P$. manokwari can easily be passively spread mainly with infested plants, plant parts and soil. The species could potentially eventually be spread from Florida throughout the US mainland, and this can be considered a significant potential threat to the whole US, the West Indies and even the rest of the Americas.

\section{Acknowledgments}

Many individuals (listed in Table 1) are thanked for forwarding photographs of the flatworms for identification. Gary Barker provided technical advices for the survey in New Caledonia. Michelle Tanguy provided the specimens of $P$. ventrolineata. Nicolas Puillandre (MNHN) helped with the analysis of the molecular results. The reviewers are thanked for their valuable help. We also thank hundreds of French 
327 and European citizens who sent photographs of non-indigenous land planarians, among which none was 328 P. manokwari.

329

330 
Álvarez-Presas M, Amaral SV, Carbayo F, Leal-Zanchet AM, and Riutort M. 2015. Focus on the details: morphological evidence supports new cryptic land flatworm (Platyhelminthes) species revealed with molecules. Organisms Diversity \& Evolution:1-25.

Álvarez-Presas M, Carbayo F, Rozas J, and Riutort M. 2011. Land planarians (Platyhelminthes) as a model organism for fine-scale phylogeographic studies: understanding patterns of biodiversity in the Brazilian Atlantic Forest hotspot. Journal of Evolutionary Biology 24:887-896.

Álvarez-Presas M, Mateos E, Tudo A, Jones H, and Riutort M. 2014. Diversity of introduced terrestrial flatworms in the Iberian Peninsula: a cautionary tale. PeerJ 2:e430.

Álvarez-Presas M, Mateos E, Vila-Farré M, Sluys R, and Riutort M. 2012. Evidence for the persistence of the land planarian species Microplana terrestris (Müller, 1774) (Platyhelminthes, Tricladida) in microrefugia during the Last Glacial Maximum in the northern section of the Iberian Peninsula. Molecular Phylogenetics and Evolution 64:491-499.

Boag B, Palmer LF, Neilson R, and Chambers SJ. 1994. Distribution and prevalence of the predatory planarian Artioposthia triangulata (Dendy) (Tricladida: Terricola) in Scotland. Annals of Applied Biology 124:165-171.

Boag B, and Yeates GW. 2001. The potential impact of the New Zealand flatworm, a predator of earthworms, in Western Europe. Ecological Applications 11:1276-1286.

Breugelmans K, Quintana Cardona J, Artois T, Jordaens K, and Backeljau T. 2012. First report of the exotic blue land planarian, Caenoplana coerulea (Platyhelminthes, Geoplanidae), on Menorca (Balearic Islands, Spain). Zookeys 199:91-105.

Cannon RJC, Baker RHA, Taylor MC, and Moore JP. 1999. A review of the status of the New Zealand flatworm in the UK. Annals of Applied Biology 135:597-614.

de Beauchamp P. 1962. Platydemus manokwari n. sp., planaire terrestre de la Nouvelle-Guinée Hollandaise. Bulletin de la Societe Zoologique de France 87:609-615.

de Beauchamp P. 1972. Planaires terrestres de Nouvelle-Guinée. Cahiers du Pacifique 16:181-192.

Eldredge LG, and Smith BD. 1995. Triclad flatworm tours the Pacific. Aliens 2:11.

Gargominy O, Bouchet P, Pascal M, Jaffré T, and Tourneur J-C. 1996. Conséquences des introductions d'espèces animales et végétales sur la biodiversité en Nouvelle-Calédonie. La Terre et la Vie : Revue d'Ecologie Appliquée 51:375-402.

Hopper DR, and Smith BD. 1992. Status of tree snails (Gastropoda: Partulidae) on Guam, with a resurvey of sites studied by H. E. Crampton in 1920. Pacific Science 46:77-85.

Jones HD. 1998. The African and European land planarian faunas, with an identification guide for field workers in Europe. Pedobiologia 42:477-489.

Jones HD. 2005. Identification: British land flatworms. British Wildlife 16:189-194.

Jones HD, Johns PM, and Winsor L. 1998. The proposed synonymy of Parakontikia ventrolineata (Dendy, 1892) and Kontikia mexicana (Hyman, 1939): what is a penis papilla? in E. Schockaert, N. Watson \& J.-L. Justine (eds), Biology of the Turbellaria. Hydrobiologia 383:91-96. 
Jones HD, Santoro G, Boag B, and Neilson R. 2001. The diversity of earthworms in 200 Scottish fields and the possible effect of New Zealand land flatworms (Arthurdendyus triangulatus) on earthworm populations. Annals of Applied Biology 139:75-92.

Justine J-L. 2014. Plathelminthes terrestres invasifs. Blog (in French). https://sites.google.com/site/jljjustine/plathelminthe-terrestre-invasif.

Justine J-L, Thévenot J, and Winsor L. 2014a. Les sept plathelminthes invasifs introduits en France. Phytoma:28-32.

Justine J-L, Winsor L, Gey D, Gros P, and Thévenot J. 2014b. The invasive New Guinea flatworm Platydemus manokwari in France, the first record for Europe: time for action is now. PeerJ 2:e297.

Kawakatsu M, Ogren RE, Froehlich EM, and Sasaki G-Y. 2002. Additions and corrections of the previous land planarian indices of the world (Turbellaria, Seriata, Tricladida, Terricola). Bulletin of the Fuji Women's College (Series 2) 40:157-177.

Kawakatsu M, Ogren RE, and Muniappan R. 1992. Redescription of Platydemus manokwari de Beauchamp, 1962 (Turbellaria: Tricladida: Terricola), from Guam and the Philippines. Proceedings of the Japanese Society of Systematic Zoology 47:11-25.

Lago-Barcia D, Fernández-Álvarez FA, Negrete L, Brusa F, Damborenea C, Grande C, and Noreña C. 2015. Morphology and DNA barcodes reveal the presence of the non-native land planarian Obama marmorata (Platyhelminthes: Geoplanidae) in Europe. Invertebrate Systematics 29:12-22.

Lázaro EM, Sluys R, Pala M, Stocchino GA, Baguñà J, and Riutort M. 2009. Molecular barcoding and phylogeography of sexual and asexual freshwater planarians of the genus Dugesia in the Western Mediterranean (Platyhelminthes, Tricladida, Dugesiidae). Molecular Phylogenetics and Evolution 52:835-845.

Littlewood DTJ, Rohde K, and Clough KA. 1997. Parasite speciation within or between host species? Phylogenetic evidence from site-specific polystome monogeneans. International Journal for Parasitology 27:1289-1297.

Lovenburg V. 2009. Terrestrial Gastropod Distributional Factors: Native and Nonnative Forests, Elevation and Predation on Mo'orea, French Polynesia. UC Berkeley: UCB Moorea Class: Biology and Geomorphology of Tropical Islands.

Lowe S, Browne M, Boudjelas S, and De Poorter M. 2000. 100 of the World's Worst Invasive Alien Species. A selection from the Global Invasive Species Database. Published by The Invasive Species Specialist Group (ISSG) a specialist group of the Species Survival Commission (SSC) of the World Conservation Union (IUCN), 12pp First published as special lift-out in Aliens 12, December 2000 Updated and reprinted version: November 2004.

Mateos E, Tudó A, Álvarez-Presas M, and Riutort M. 2013. Planàries terrestres exòtiques a la Garrotxa. Annals de la Delegació de la Garrotxa de la Institució Catalana d'Història Natural 6:67-73.

Menzies DW. 1959. Picro-Gomori method. Stain Technology 34:294-295.

Murchie AK, and Gordon AW. 2013. The impact of the "New Zealand flatworm", Arthurdendyus triangulatus, on earthworm populations in the field. Biological Invasions 15:569-586.

Purea M, Matalavea S, Bourke T, and Hunter D. 1998. Platydemus manokwari de Beauchamp, a flatworm predator of the giant African snail (Achatina fulica Bowdich) recorded in Samoa. Journal of South Pacific Agriculture 5:71-72. 
Saitou N, and Nei M. 1987. The neighbor-joining method: a new method for reconstructing phylogenetic trees. Molecular Biology and Evolution 4:406-425.

Schröder O. 1924. Landplanarien von Neu-Caledonien und den Loyalty-Inseln. In: F. Sarasin \& J. Roux (Eds) Nova Caledonia. A Zoologie. Vol. 3: 259-298. Kreidel Verlag: Berlin.

Sheppard PJ. 2011. Lapita Colonization across the Near/Remote Oceania Boundary. Current Anthropology 52:799-840.

Tamura K, Stecher G, Peterson D, Filipski A, and Kumar S. 2013. MEGA6: Molecular Evolutionary Genetics Analysis Version 6.0. Molecular Biology and Evolution 30:2725-2729.

Thévenot J, Justine J-L, and Rome Q. 2014. Surveillance des espèces animales invasives en France, implication des sciences participatives. Premières assises nationales sur les espèces exotiques envahissantes « Espèces exotiques envahissantes : Vers un renforcement des stratégies d'action "Organized by: Comité Français de l'Union International de Conservation de la Nature (UICN), Orléans, France, 23-25 September 2014 http://dxdoiorg/106084/m9figshare1157786.

Winsor L. 1990. Taxonomic studies on free-living flatworms (Turbellaria: Platyhelminthes) of the Australian Zoogeographic Region. Chapter 4: Taxonomy and biology of a molluscivorous terrestrial flatworm Platydemus manokwari Beauchamp, 1962. MSc thesis. James Cook University: Townsville.

Winsor L. 1991. A new genus and species of terrestrial flatworm from the central highlands of New Caledonia (Tricladida: Terricola). in: J. Chazeau \& S. Tillier (Eds), Zoologia Neocaledonica, volume 3. Mémoires du Muséum National d'Histoire Naturelle, série A 149:19-30.

Winsor L. 1998. Aspects of the taxonomy and functional histology in terrestrial flatworms (Tricladida: Terricola). Pedobiologia 42:412-432.

Winsor L, Johns PM, and Barker GM. 2004. Terrestrial planarians (Platyhelminthes: Tricladida: Terricola) predaceous on terrestrial gastropods. In: Barker GM, ed. Natural enemies of terrestrial molluscs. Oxfordshire, UK: CAB International, 227-278. 
Table $\mathbf{1}$ (on next page)

Origin of Platydemus manokwari specimens and observations 


\section{Table 1. Origin of Platydemus manokwari specimens and observations.}

\begin{tabular}{|c|c|c|c|c|c|c|}
\hline Locality & Collector and/or photographer & Photos & $\begin{array}{l}\text { Date } \\
\text { (dd/mm/yyyyy) }\end{array}$ & $\begin{array}{l}\text { Specimen } \\
\text { deposition } \\
\text { (H: histology) }\end{array}$ & $\begin{array}{l}\text { COI Sequence } \\
\text { (GenBank \#) }\end{array}$ & $\begin{array}{l}\text { COI } \\
\text { Haplotype }\end{array}$ \\
\hline \multicolumn{7}{|l|}{ France } \\
\hline Caen, hothouse in Jardin des Plantes & FREDON Basse Normandie & & $29 / 10 / 2013$ & MNHN JL81 & $\begin{array}{l}\text { Short: KF887958 } \\
\text { (identical in } 3 \text { specimens) } \\
\text { Long: KR349594 }\end{array}$ & World \\
\hline Caen, hothouse in Jardin des Plantes & FREDON Basse Normandie & & $15 / 04 / 2014$ & MNHN JL139 (H) & Long: KR349597 & World \\
\hline \multicolumn{7}{|l|}{ French Polynesia } \\
\hline Fa'a'ā, Tahiti, altitude: sea level & Jonas Fernandez & + (Fig. 4) & $26 / 05 / 2014$ & MNHN JL151 & Short: KR349595 & World \\
\hline $\begin{array}{l}\text { Moorea, Tahiti, Mt Aorai trail, altitude } \\
1000 \mathrm{~m}\end{array}$ & Jean-Yves Meyer & + & $19 / 06 / 2013$ & & & \\
\hline \multicolumn{7}{|l|}{ Wallis and Futuna } \\
\hline Wallis, Uvéa, near Lac Lalolalo & Jean-Yves Meyer & + & $10 / 11 / 2007$ & & & \\
\hline Futuna, locality not registered & Jean-Yves Meyer & + & $10 / 11 / 2008$ & & & \\
\hline \multicolumn{7}{|l|}{ New Caledonia, mainland } \\
\hline Nouméa, quartier Vallée des Colons & Nicolas Rinck & + & $09 / 04 / 2014$ & MNHN JL107B & Short: KR349596 & World \\
\hline Nouméa, quartier N’Géa & Claire Goiran & + (Fig. 3) & $29 / 07 / 2014$ & & & \\
\hline \multirow[t]{2}{*}{ Nouméa, quartier N’Géa } & Claire Goiran, specimens CEN\#2500-2501 & & $25 / 12 / 2014$ & MNHN JL221A & & \\
\hline & & & & MNHN JL221B & & \\
\hline Nouméa, quartier Motor Pool & Vanessa Héquet & & 06/09/2014 & & & \\
\hline Mont-Dore, Saint Michel & Ludivine Sariman, specimen CEN\#2496 & & $01 / 10 / 2014$ & MNHN JL197 & Short: KR349600 & World \\
\hline Païta, Tontouta & $\begin{array}{l}\text { Gazmira Machin-Baucher, specimen } \\
\text { CEN\#2497 }\end{array}$ & & $12 / 10 / 2014$ & MNHN JL198 & Short: KR349601 & World \\
\hline Païta, Ondémia & Patrick Barrière, specimens CEN\#2502-2503 & + & 08/01/2015 & $\begin{array}{l}\text { MNHN JL222A } \\
\text { MNHN JL222B }\end{array}$ & & \\
\hline Hienghène, quartier Pai Kalone & Cyrille Sabran, specimens CEN\#2504-2505 & & $26 / 01 / 2015$ & MNHN JL223A & & \\
\hline La Foa, quartier Nily & Jörn Theuerkauf, specimen CEN\#2506 & & $21 / 02 / 2015$ & MNHN JL234 & Long: GenBank xxx & World \\
\hline Koné, Foué (CEN) & Patrick Barrière, specimens CEN\#2507 & & $27 / 02 / 2015$ & MNHN JL235A & Long: GenBank xxx & World \\
\hline Koné, Foué (CEN) & Patrick Barrière, specimens CEN\#2594 & & 03/04/2015 & & & \\
\hline Koné, Paiamboue & Nathalie Baillon, specimen CEN\#2596 & & $11 / 04 / 2015$ & & & \\
\hline Koné, Tribu de Tiaoué & Hervé Vandrot, specimens CEN\#2508 & & $02 / 03 / 2015$ & $\begin{array}{l}\text { MNHN JL236A } \\
\text { MNHN JL236B }\end{array}$ & $\begin{array}{l}\text { Long: GenBank xxx } \\
\text { Long: GenBank xxx }\end{array}$ & $\begin{array}{l}\text { World } \\
\text { World }\end{array}$ \\
\hline
\end{tabular}


Koné, Village, rue Paul Amat

Poya, Lot 16 , Section village

Poya, Népou

\section{New Caledonia, Lifou Island}

Tribu de Hnassé

New Caledonia, Maré Island

Tribu de Maré, Limite

\section{Singapore}

Opera Estate, Fidelio Street

Chestnut Avenue

Tanah Merah

Admiralty Park

Secondary forest, end of Sunset Way

\section{Solomon Islands}

Guadalcanal, Foxwood, east of Honiara

Guadalcanal, Henderson, east of Honiara

Guadalcanal, Dodo Creek, east of Honiara

Crispus Fanai \& Francis Tsatsia, specimen examined by LW, LW1805

Ken Cadin, specimen CEN\#2510

Béatrice Bresse, specimen CEN\#2509

Nicolas Bazire, specimen CEN\#2592

Lory Richard, specimen CEN\#2591

Jean-Paul Lolo, specimen CEN\#2593

Marcel Pijone, specimen CEN\#2595

Andrew Wee Kien Han

Personal blog **, photos by "James" Personal blog **, photo by "Ivan Kwan" Personal blog **, photo by "Ivan Kwan" Personal blog **, photo by "James"

Benjamin Paul Yi-Hann Lee

Crispus Fanai examined by LW, LW1804 Dumbéa, La Couvelée

Crispus Fanai \& Francis Tsatsia, specimen

Guadalcanal, West Honiara, Tasahe Drive
$08 / 2014$

$09 / 2014$

(1)

$05 / 03 / 2015$

$02 / 03 / 2015$

$08 / 03 / 2015$

MNHN JL238

MNHN JL237

Long: GenBank xxx

Long: GenBank xxx

World

World

03/03/2015

$11 / 04 / 2015$

$\begin{array}{ll}+ \text { (Fig. 2) } & 20 / 03 / 2014 \\ & \\ + & 05 / 02 / 2011 \\ + & 17 / 07 / 2010 \\ + & 18 / 04 / 2011 \\ + & 22 / 07 / 2010 \\ + & 01 / 01 / 2014\end{array}$

MNHN JL148A

Long: KR349579

MNHN JL148B

Long: KR349580

World

World

MNHN JL199

MNHNJL200A

MNHN JL200B

MNHN JL200C

MNHN JL200D

MNHN JL201A (H)

MNHN JL201B (H)

MNHN JL201C

MNHN JL201D

MNHN JL201E

MNHN JL201F $(H)$

MNHN JL201G (H)

MNHN JL201H

MNHN JL201

MNHN JL201J

05/04/2015
Short: KR349602

Short: KR349603

Short: KR349604

Short: KR349605

Short: KR349606

Long: KR349593

Short: KR349607

Short: KR349586

Short: KR349608

Short: KR349609

Long: KR349588

Long: KR349589

Long: KR349590

Long: KR349591

Long: KR349592
Australian 1

Australian 1

Australian 1

Australian 1

Australian 1

Australian 1

Australian 1

World

World

Australian 1

World

World

World

World

World 


\section{Guam}

Quenga turnoff on Sengsong Road (28)

David G. Robinson, specimen USDA \#: 04-

$17 / 08 / 2004$

MNHN JL191

Not obtained

Alongside road to Ritidian Point

GU-11

David G. Robinson, specimen USDA \#: 05-

$22 / 08 / 2005$

MNHN JL192

Not obtained

GUAM-15

\section{USA, Florida}

Miami, NW 5th Avenue

Miami, SW 122 Street

Miami, SW 192 Terrace

Mary Yong Cong, specimen DPI\#: WP\#2

Anibal Altamirano, specimen DPI\#: none

10/08/2012 MNHN JL189

MNHN JL190

Short: KR349598

Mary Yong Cong \& Juan Suarez, DPI\#: none

USDA 140203

Coral Gables, Montgomery Botanical

Makiri Sei

+ (Fig. 1) 14/08/2014

Gardens, Old Cutler Road

\section{USA, Puerto Rico}

San Juan

Giomara La Quay

Dec/2014

MNHN JL207A

Short: KR349610

World

MNHN JL207B

Short: KR349611

World

\section{Australia, Queensland}

Townsville, Palmetum, Douglas

Townsville, Palmetum, Douglas

Leigh Winsor, specimens LW1795

Leigh Winsor, specimens LW1795

17-09-2014

$17-09-2014$

MNHN JL179A

MNHN JL179B

Long: KR349583

eigh Winsor, specimen LW1796

$17-09-2014$

MNHN JL180

28-10-2009

MNHN JL178B

Long: KR349584

Leigh Winsor, specimens LW1794

28-10-2009

Long: KR349585

Long: KR349582

Long: KR349581
World

World

Leigh Winsor, specimens LW1794

Australian 1

Australian 1

Australian 1

Australian 1

Australian 2

3

** Available from: http://lazy-lizard-tales.blogspot.co.uk/2011/12/ribbons-terrestrial-nemerteans-of.html (maintained by Ivan Kwan) 


\section{Table 2 (on next page)}

Morphological data of specimens with known haplotype

Specimens with "World haplotype" apparently differ from specimens with "Australia haplotype" only by the ratio length of penis papilla: length of body. Given our small sample size we conclude that no morphological difference can reliably differentiate the two haplotypes. 


\begin{tabular}{|c|c|c|c|c|}
\hline Specimen & Haplotype & $\begin{array}{l}\text { Length of body } \\
(\mathrm{mm})\end{array}$ & $\begin{array}{l}\text { Length of } \\
\text { penis papilla } \\
(\mu \mathrm{m})\end{array}$ & $\begin{array}{l}\text { Ratio } \\
\text { length of penis } \\
\text { papilla: length of } \\
\text { body } \\
(\%)\end{array}$ \\
\hline MNHN JL139 & World & 44.5 & 639 & 1.4 \\
\hline MNHN JL201F & World & 22.5 & 355 & 1.6 \\
\hline MNHN JL201G & World & $\begin{array}{l}18+(1-2 \mathrm{~mm} \text { of } \\
\text { tip missing })\end{array}$ & 320 & 1.7 \\
\hline $\begin{array}{l}\text { LW } 1065 \\
\text { (used for GenBank AF178320) }\end{array}$ & Australian & 45.0 & 315 & 0.7 \\
\hline MNHN JL201A & Australian & 28.0 & 213 & 0.7 \\
\hline MNHN JL201B & Australian & 26.5 & 256 & 0.9 \\
\hline
\end{tabular}

2 
PeerJ Reviewing Manuscript

1

Platydemus manokwari in Coral Gables, Florida, USA.

Photograph by Makiri Sei.

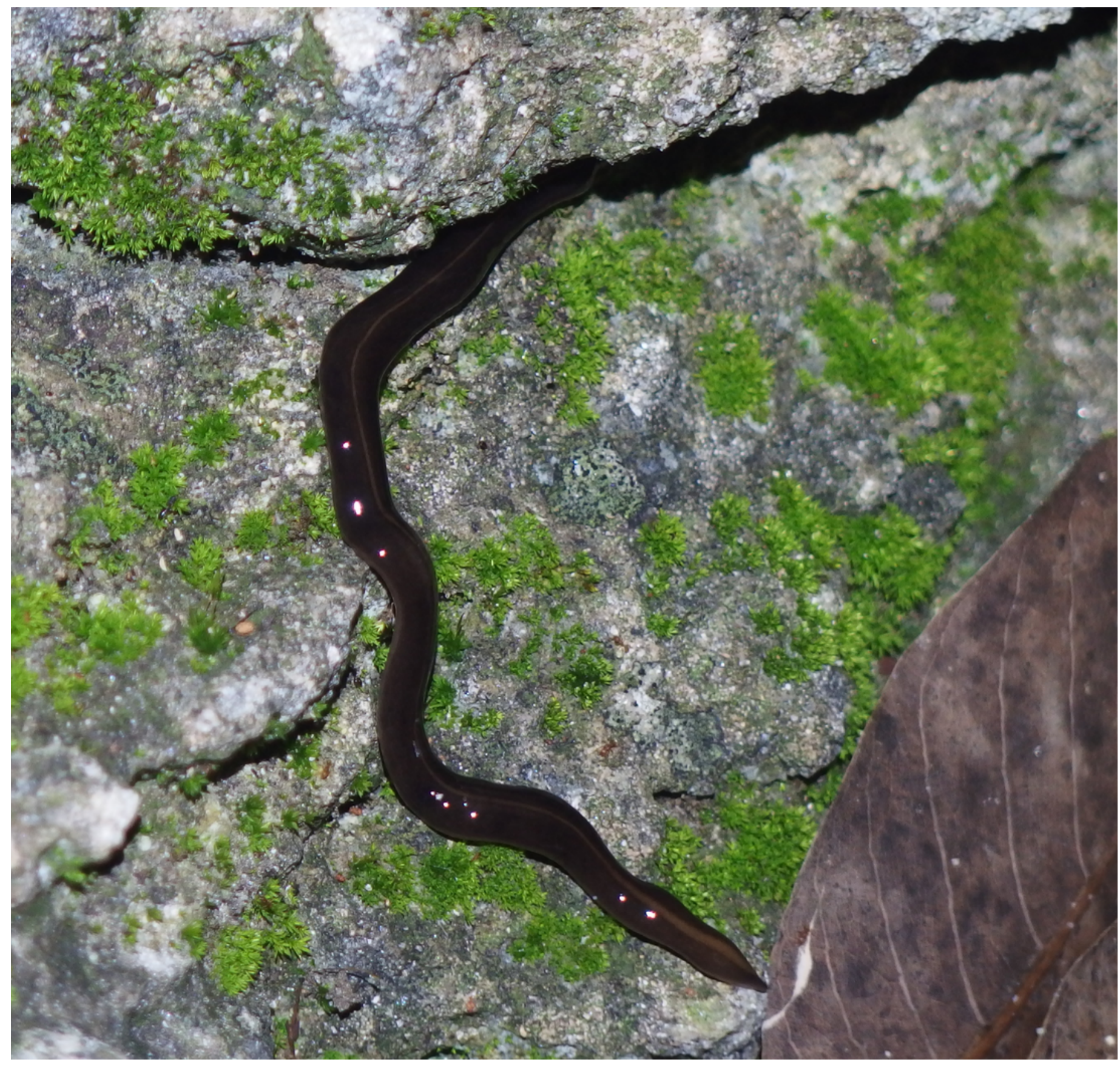


2

Platydemus manokwari in Singapore.

Photograph by Andrew Wee Kien Han.

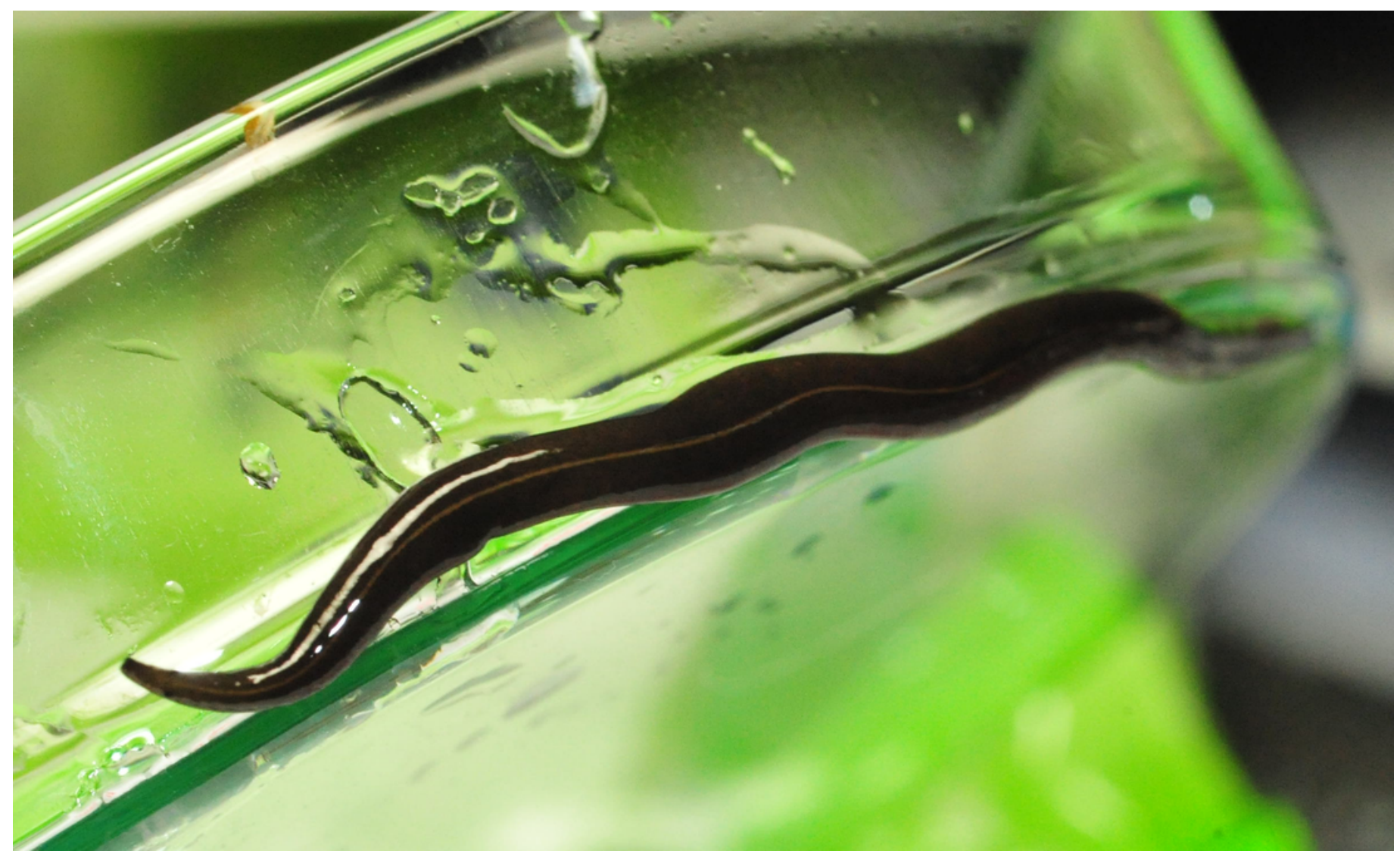


3

Platydemus manokwari in Nouméa, New Caledonia.

Photograph by Claire Goiran. Scale: $\mathrm{cm}$ and $\mathrm{mm}$.

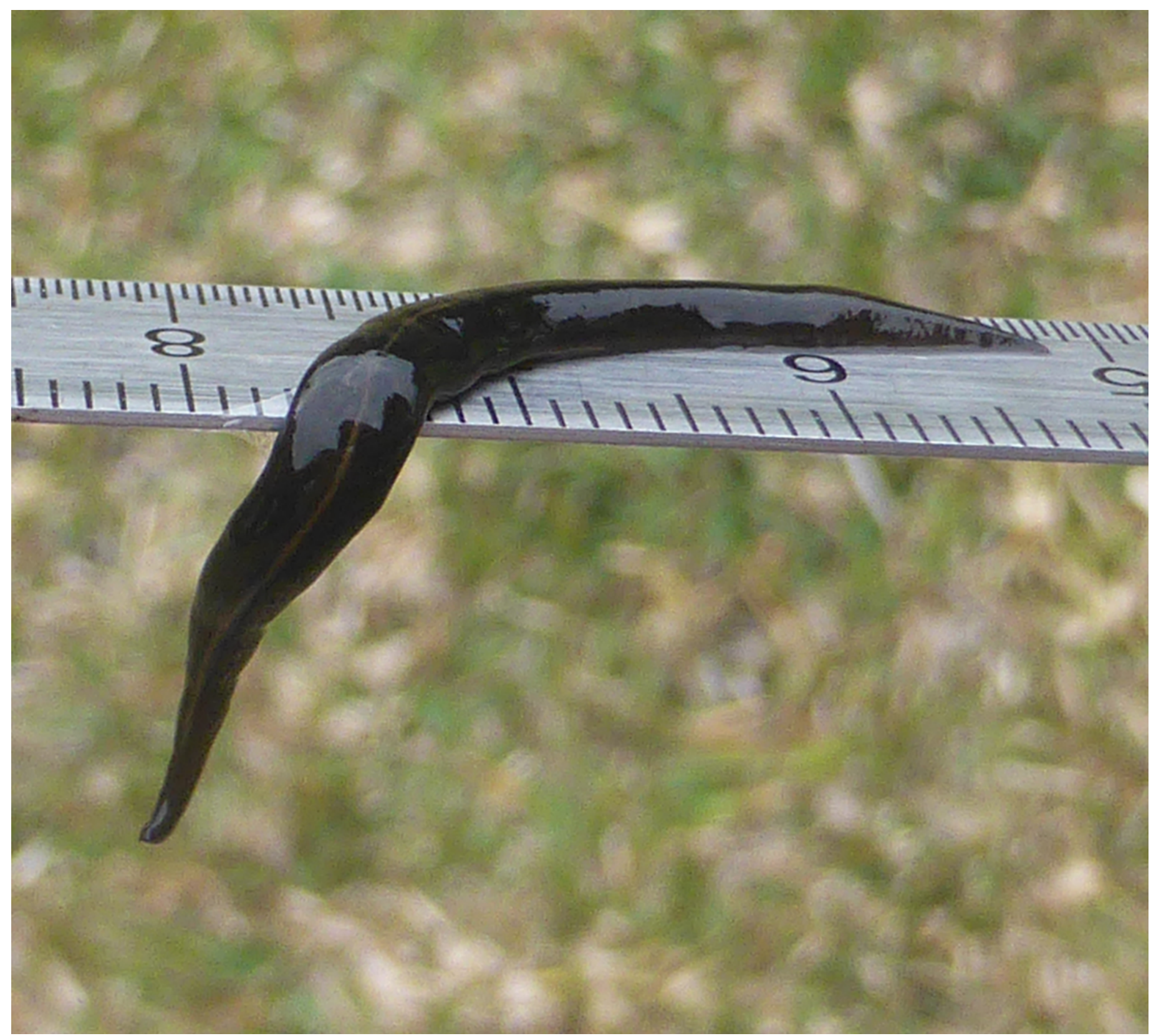


4

Figure 4. Platydemus manokwari in Fa'a'ā, Tahiti, French Polynesia.

Photograph by Jonas Fernandez. Scale: $\mathrm{cm}$ and $\mathrm{mm}$.

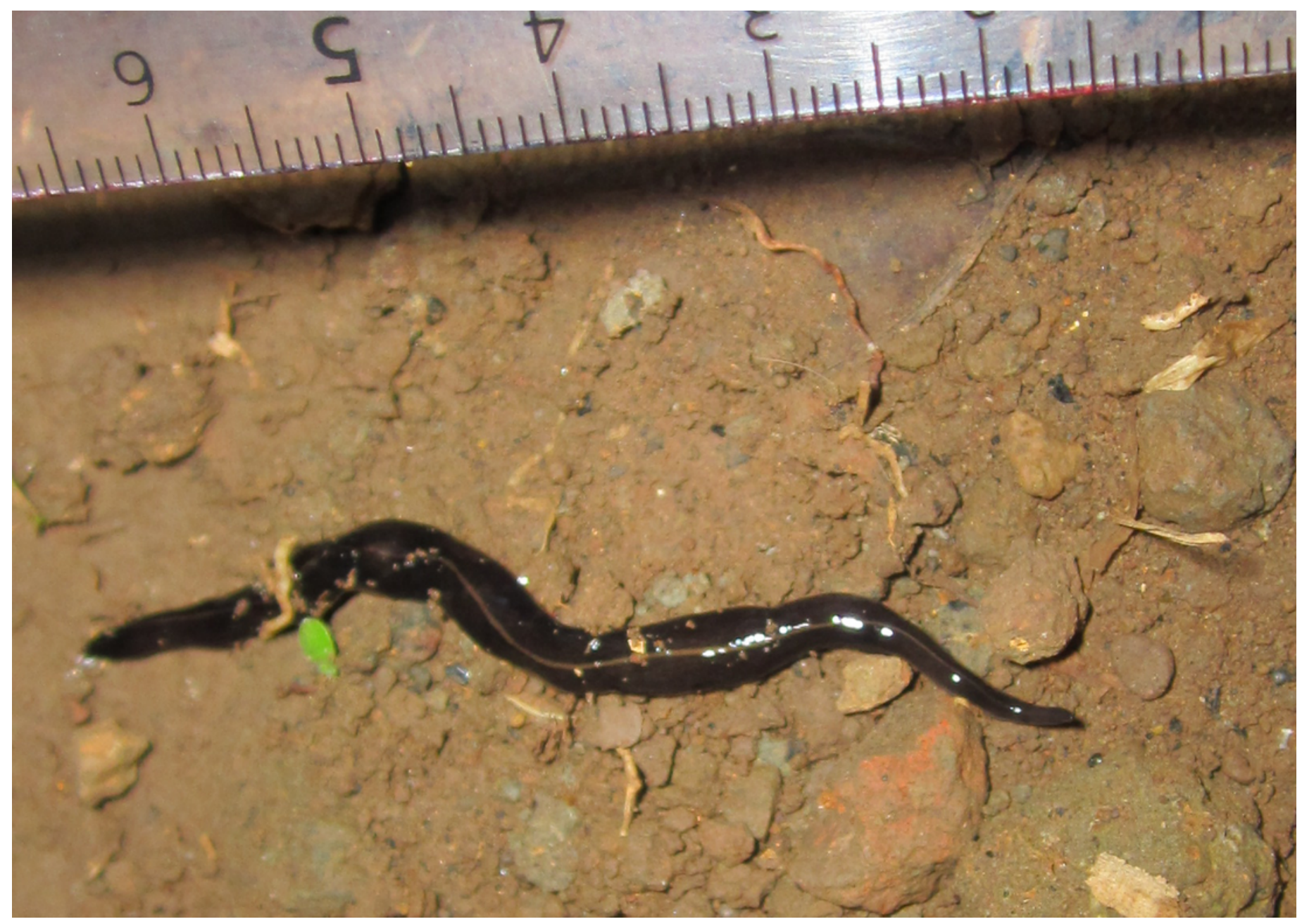




\section{5}

Platydemus manokwari: Tree based on short COI sequences.

'Short' sequences, 424 bp in length, were obtained from 38 specimens. In this tree, only one sequence was used for each locality or for each haplotype when variation was found (Dodo Creek, Solomon Island). Two clades are well differentiated: haplotype "World" and haplotype "Australian". The tree was constructed using the Neighbour-Joining method. The scale bar indicates the number of substitutions per site.

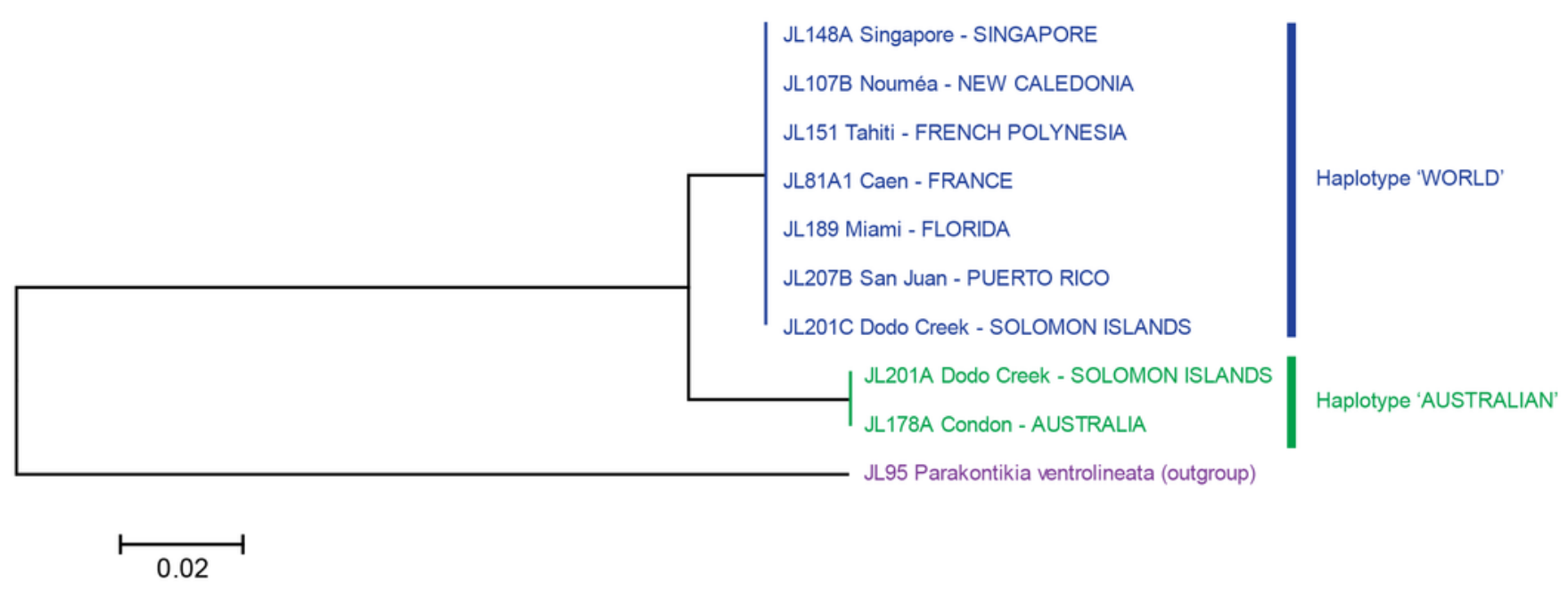




\section{6}

Platydemus manokwari: tree based on long COI sequences.

'Long' sequences, 909 bp in length, were obtained with two pairs of primers from 21 specimens. In this tree, only one sequence was used for each locality or for each haplotype when variation was found. Two clades are well differentiated: haplotype "Australian" (with a minor 1 bp variation in one sequence, labelled as "Australian 2") and haplotype "World". The tree was constructed using the Neighbour-Joining method. The scale bar indicates the number of substitutions per site.

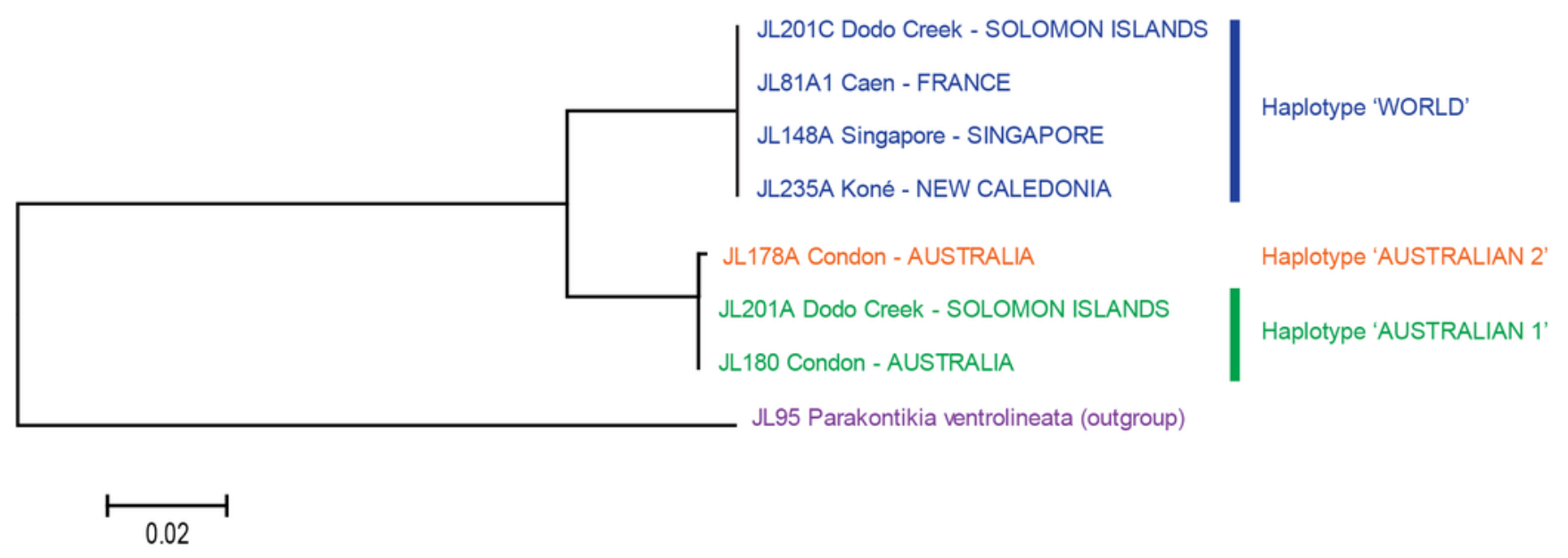




\section{7}

Platydemus manokwari, map of distribution records.

Blue: previous records (Justine et al. 2014b) ; Red: new records reported in this paper.

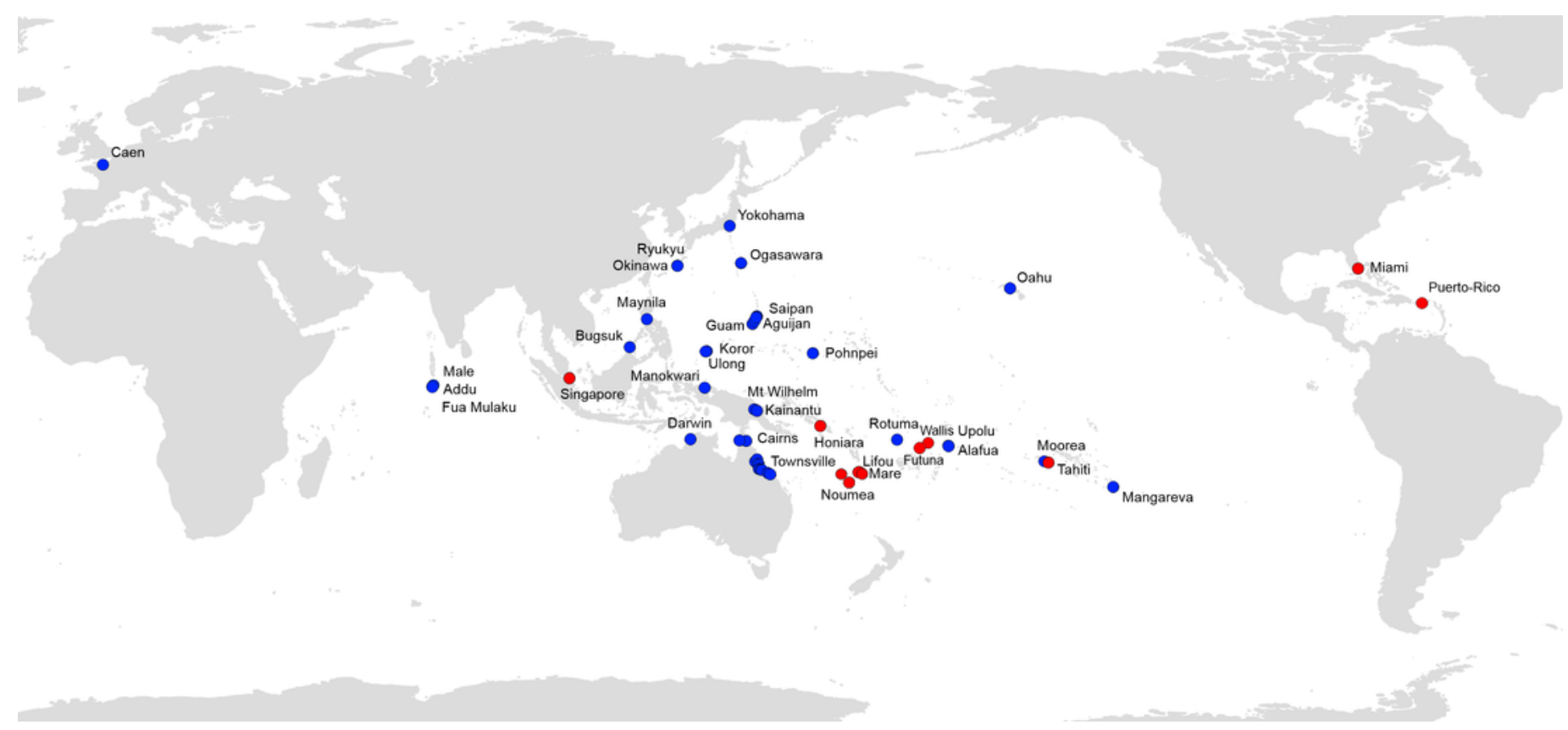

